\title{
RELATO DE EXPERIÊNCIA \\ INCLUSÃO DE TÉCNICOS E AUXILIARES DE ENFERMAGEM NO COMITÊ DA QUALIDADE-ESTRATÉGIA PARA EVOLUÇÃO DOS PROCESSOS DE QUALIDADE E SEGURANÇA DO PACIENTE
}

Daise Guilherme1; Danielle Helena dos Santos Silva²; Antonia Resende ${ }^{3}$

\section{RESUMO}

O presente trabalho relata a experiência de um hospital, que além dos membros da alta gestão optou por incluir ao corpo do Comitê da Qualidade técnicos e auxiliares de enfermagem que fizeram a diferença para o objetivo de melhoria contínua, acreditação hospitalar e segurança do paciente.

\section{DESENVOLVIMENTO}

Dentre os inúmeros motivos e estratégias do grupo para o desafio de se internalizar conceitos e praticas destacamos: as metas internacionais de segurança do paciente onde o grupo utilizou a dinâmica educativa itinerante. Setores e turnos foram visitados por pessoas tematicamente caracterizadas que estimulavam de forma lúdica através de questões retiradas do "baú da qualidade", conceito e aplicabilidade de cada meta nas atividades diárias.

\section{INTRODUÇÃO}

\section{DINÂMICA NAS UNIDADES}

Podemos compreender que Qualidade é um processo dinâmico, uma ferramenta de apoio que visa melhorias constantes, gestão organizacional e inovação para busca de excelência por meio de práticas racionais, focadas nas demandas dos clientes ${ }^{1}$.No entanto, antes de executar qualquer ação que promova a cultura de segurança na instituição, ela deve, em primeiro lugar, ser avaliada e compreendida. ${ }^{2}$

De acordo com as diretrizes do Comitê da Qualidade o que ocorre é uma multiplicação de cultura por todas as lideranças. ${ }^{3}$ Porém a experiência obtida é a de que técnicos e auxiliares de enfermagem, compondo um Comitê da Qualidade foram suporte diferencial para o processo de acreditação hospitalar

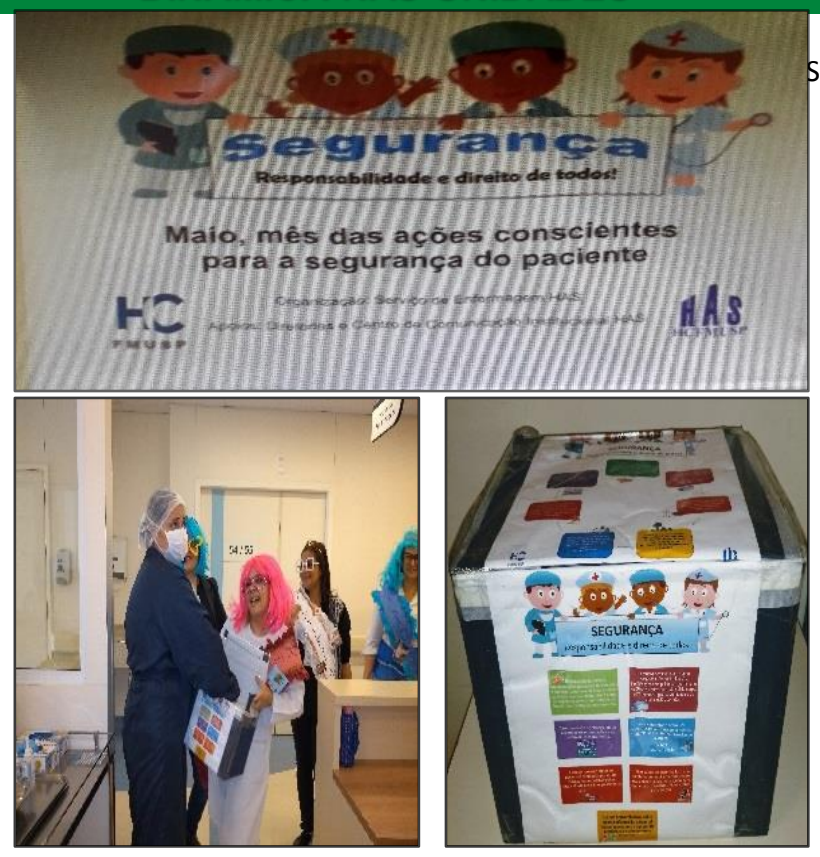
estimulando e realizando ações assertivas.

\section{CONCLUSÃO}

Para o Comitê da Qualidade a inclusão do grupo como suporte foi e tem sido de suma importância para a disseminação da cultura de segurança do paciente acreditação hospitalar e das demais temáticas, possibilitando avanços nos processos de melhoria da qualidade com maior fluidez e aceitabilidade em todos os níveis hierárquicos.

\section{REFERÊNCIAS}

1 ROCHA, Alberto Carlos. A importância do Comitê da Qualidade nos programas de Gestão da Qualidade, 2012.

2 ALÁSTICO Pedro Gabriel, TOLEDO, de Carlos José. Acreditação Hospitalar: proposição de roteiro para implantação,2013

3 GESTÃO DA QUALIDADE, Diretrizes para a qualidade no gerenciamento de Projetos, NBR ISO 10006. Acesso em: $04 / 11 / 2018$

Elaborado por: ${ }^{1}$ Enfermeira, pela Universidade de Mogi das Cruzes SP Gestão da Qualidade pela Fiocruz HCFMUSP; ${ }^{2}$ Enfermeira, pela faculdade Mogi das

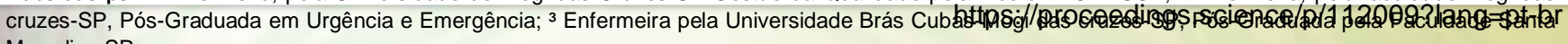

